\title{
PENGARUH KONFLIK KERJA TERHADAP STRESS KERJA DAN DAMPAKNYA PADA MOTIVASI KERJA SERTA KINERJA KARYAWAN HOTEL DI JEMBER
}

\author{
Faozen \\ Program Perhotelan, Fakultas Ilmu Sosial dan Ilmu Politik \\ Universitas Muhammadiyah Jember, Indonesia \\ faozen@unmuhjember.ac.id
}

\begin{abstract}
Abstrak
Adanya konflik kerja berdapak pada stres kerja yang mengakibatkan menurunnya motivasi kerja dan kinerja karyawan. Motivasi kerja sangat diperlukan oleh setiap individu karyawan sebagai pemacu untuk menciptakan gairah kerja. Kinerja karyawan timbul sebagai respon efektif terhadap tugas pekerjaan yang dilakukan oleh karyawan. Penelitian ini dimaksudkan untuk menguji variabel konflik kerja terhadap stress kerja, motivasi kerja serta kinerja karyawan sebagai variabel tidak bebas.populasi penelitian ini adalah para karyawan hotel di Jember dengan sampel 120 orang, penetapan sampel dengan metode accidental samplingHasil penelitian ini menunjukkan bahwa variable konflik kerja berpengaruh positif dan signifikan terhadap stress kerja secara langsung. variable konflik kerja berpengaruh positif dan signifikan terhadap stress kerja secara langsung.variable konflik kerja berpengaruh nigatif dan signifikan terhadap motivasi kerja secara langsung.variable konflik kerja berpengaruh nigatifdan tidak signifikan signifikan terhadap kinerja karyawan secara langsung. variable stress kerja berpengaruh nigatif dan tidak signifikan terhadap motivasi kerja secara langsung. variable stress kerja berpengaruh positif dan tidak signifikan terhadap kinerja karyawan secara langsung.variable motivasi kerja berpengaruh positif dan signifikan terhadap kinerja karyawan secara langsung.variable konflik kerja berpengaruh positif dan signifikan terhadap stress kerja secara langsung.variable konflik kerja berpengaruh nigatif dan signifikan terhadap motivasi kerja melalui stress kerja.variable konflik kerja berpengaruh nigatif dan signifikan terhadap kinerja karyawan melalui stress kerja dan motivasi kerja.variable stress kerja berpengaruh nigatif dan tidak signifikan terhadap kinerja karyawan melalui motivasi kerja.
\end{abstract}

Keyword: konflik kerja, stress kerja, motivasi kerja, kinerja karyawan

\begin{abstract}
The existence of work conflict based on work stress that results in decreased work motivation and employee performance. Work motivation is needed by every individual employee as a booster to create work passion. Employee performance arises as an effective response to work tasks performed by employees. This study is intended to examine the variables of work conflict on work stress, work motivation and employee performance as dependent variables. The population of this study is hotel employees in Jember with a sample of 120 people, determination of the sample by accidental sampling method. The results of this study indicate that the work conflict variable a positive and significant effect on work stress directly. Work conflict variable has a positive and significant effect on work stress directly. Work conflict variables have a significant and nigative effect on work motivation directly. Work conflict variables have a nigative effect and are not significant significantly on employee performance directly. Work stress variable is nigative and has no significant effect on work motivation directly. Work stress variable has a positive and not significant effect on employee performance directly. Work motivation variable has a positive and significant effect on employee performance directly. Work conflict variable has a positive and significant effect on work stress directly. Work conflict variable is significant and significant to work motivation through work stress. Work conflict variable has a significant and negative effect on employee performance through work stress and work motivation. Work stress variable is nigative and has no significant effect on employee performance through work motivation.

Keyword: work conflict, work stress, work motivation, employee performance
\end{abstract}


Sadar Wisata: Jurnal Pariwisata

(p- ISSN 1858-0112, e-ISSN 15537-37677)

\section{INTRODUCTION}

Karyawan merupakan salah satu faktor penting yang perlu diperhatikan oleh perusahaan guna mencapai tujuannya perusahaan. Hal ini perusahaan dituntut kemampuannya dalam mengelola sumbersumber daya secara terencana, terutama sumber daya manusia sebagai tenaga operasional di perusahaan untuk menghasilkan daya guna dan hasil guna dalam setiap kegiatan perusahaan (Ramdhani:2011).

Karyawan mendapatkan tantangan bertambah berat menghadapi permintaan perusahaan yang memiliki stardar kinerja tinggi guna kelangsungan perusahaan. Perkembangan organisasi tidak lepas dari perubahan teknologi yang selalu berkembang guna mendukung system manajemen perusahaan baik itu mesing maupun peralatan yang canggih, (baik opersional maupun administrasi). Dengan adanya perubahan yang begitu pesat perusahaan harus menyesuaikan dengan perubahan yang begitu cepat dengan adanya teknologi tersebut. Guna mendukung perkembangan tersebut perusahaan mau tidak mau harus mengupgrade tengakerjanya paling tidak dengan pelatihan-pelatihan secara terus menerus bagi karyawan baik yang baru maupun yang lama (Yuli.2010)

Tantangan yang berat itulah membuat karyawan menjadi stress atau frustasi pada karyawan hotel dan tidak menutup kemungkina menjadi konflik kerja yang akan menimbulkan ketegangan yang sering menjelma dalam sikap dan tingkahlaku yang agresif, kritikan, memberontak, dan atau perilaku yang lainnya, dengan adanya tantangan yang makin berat membuat karyawan semakin beban dalam bekerja, dengan beban kerja yang cukup tinggi bisa saja berakibat menimbulkan kelelahan dalam bekerja, maka akan membuat karyawan itu stress kerja dan konfli kerja
Volume 3 No. 1 Juni Tahun 2020

http://jurnal.unmuhjember.ac.id/index.php/wisata

muncul dalam lingkungan perusahaan (Yuli:2010)

Semakin majunya teknoligi, tenaga kerja juga semakin diharapkan kontribusinya pada perusahaan dengan meningkatkan kualitas kinerjanya yang menjadi modal dasar dan menjadi kunci keberhasilan tujuan perusahaan tersebut melalui profesionalisme, kemadirian, etos kerja, dan produktivitas kerja, hal ini diperlukan tenaga kerja dan lingkungan kerja yang sehat, aman, nyaman, dan menjamin peningkatan produktivitas kerja (Yuli:2010).

Stress dan konflik yang dialami karyawan jika dibiarkan berlarut-larut tanpa adanya penyelesaian akan dampak negatif bagi karyawan itu sendiri maupun perusahaan. Dampak negatif bagi karyawan adalah terjadinya penurunan prestasi kerja karyawan, misalnya target penjualan tidak tercapai, kesehatan karyawan menjadi menurun dan akhirnya terjadi kondisi dimana karyawan tidak dapat melaksanakan pekerjaannya. Sedangkan dampak negatif bagi perusahaan adalah penurunan pendapatan perusahaan sebagai akibat dari penurunan hasil kerja karyawan (Yuli:2010). Disinilah motivasi diperlukan yakni sebagai suatu yang menimbulkan semangat atau dorongan kerja yang berdampak pada kinerja karyawan (produktifitas kerja).

\section{METODOLOGI}

Rancangan penelitian ini merupakan penelitian penjelasan (explanatory research) dimana bertujuan untuk menjelaskan hubungan - hubungan antara satu variabel dengan variabel lainnya dan juga termasuk dalam penelitian konfirmatori (confirmatory research) karena tujuannya menjelaskan hubungan kausal antar variabel melalui pengujian hipotesis (Singarimbun dan Efendi dalam Dimyati, 2009). 
Sadar Wisata: Jurnal Pariwisata

(p- ISSN 1858-0112, e-ISSN 15537-37677)

\section{Definisi Operasional Konflik Kerja}

Konflik umumnya diartikan sebagai pertentangan. Hal ini senada dengan Owens (1995: 147) yang mendefinisikan konflik sebagai suatu hal yang mucul bila terdapat ketidaksesuaian atau pertentangan. Adapun Robbins (2003) menguraikan konflik sebagai suatu proses yang timbul karena pihak pertama merasa bahwa pihak lain memberi pengaruh negatif atau akan segera mempengaruhi secara negatif terhadap yang diharapkan oleh pihak pertama. Dengan demikian sesungguhnya konflik dapat muncul di mana saja, kapan saja, dan pada siapa pun selagi ada ketidakcocokan atau pertentangan

\section{Definisi OperasionalStress Kerja}

Gibson et al (dalam Yulianti, 2000:9) mengemukakan bahwa stress kerja dikonseptualisasi dari beberapa titik pandang, yaitu stres sebagai stimulus, stres sebagai respon dan stres sebagai stimulus-respon. Luthans (dalam Yulianti, 2000:10) mendefinisikan stres sebagai suatu tanggapan dalam menyesuaikan diri yang dipengaruhi oleh perbedaan individu dan proses psikologis, sebagai konsekuensi dari tindakan lingkungan, situasi atau peristiwa yang terlalu banyak mengadakan tuntutan psikologis dan fisik seseorang, Dengan demikian dapat disimpulkan bahwa stres kerja timbul karena tuntutan lingkungan dan tanggapan setiap individu dalam menghadapinya dapat berbeda.

\section{Definisi Operasional Motivasi Kerja}

Abraham Sperling (dalam Mangkunegara, 2002:93) mengemukakan bahwa motif di definisikan sebagai suatu kecenderungan untuk beraktivitas, dimulai dari dorongan dalam diri (drive) dan diakhiri dengan penyesuaian diri- Penyesuaian diri dikatakan untuk memuaskan motif. William J. Stanton (dalam Mangkunegara, 2002:93) mendefinisikan bahwa motif adalah kebutuhan yang di stimulasi yang berorientasi kepada tujuan individu dalam
Volume 3 No. 1 Juni Tahun 2020

http://jurnal.unmuhjember.ac.id/index.php/wisata

mencapai rasa puas. Motivasi didefinisikan oleh Fillmore H. Stanford (dalam Mangkunegara, 2002:93) bahwa motivasi sebagai suatu kondisi yang menggerakkan manusia ke arah suatu tujuan tertentu. Sedangkan (Mangkunegara, 2001: 68), mengatakan bahwa motivasi berbentuk dari sikap (Attitude) seorang pegawai dalam menghadapi situasi (situation) kerja. Motivasi merupakan kondisi yang menggerakkan diri pegawai yang terarah untuk mencapai tujuan organisasi (tujuan kerja). Menurut Nawawi (2001: 351), bahwa kata motivasi (motivation) kata dasarnya adalah motif (motive) yang berarti dorongan, sebab atau alasan seseorang melakukan sesuatu. Dengan demikian motivasi berati suatu kondisi yang mendorong atau menjadikan sebab seseorang melakukan suatu perbuatan/ kegiatan yang berlangsung secara sadar. Menurut Sedarmayanti (2001: 66), motivasi dapat diartikan sebagai suatu daya pendorong (driving force) yang menyebabkan orang berbuat sesuatu atau yang diperbuat karena takut akan sesuatu

\section{Definisi Operasional Kinerja Karyawan}

Kinerja adalah istilah yang populer di dalam manajemen, yang mana istilah kinerja didefinisikan dengan istilah hasil kerja, prestasi kerja dan performance. Menurut The Sriber Bantam English Dictionary terbitan Amerika Serikat dan Canada, tahun 1979 (dalam Prawirosentono, 1999:1-2) "to perform" mempunyai beberapa "entries" berikut: (1) to do or Carry out; executive, (2) to discharge or fulfill, as a vow, (3) to party, as a character in a play, (4) to render by the voice or musical instrument, (5) to execute or complete on undertaking, (6) to act a part in a play, (7) to perform music, (8)to do what is expected of person or machine. 


\section{Metode Mengumpulkan Data}

Penelitian ini menggunakan metode angket atau kuesioner Oleh karena itu wawancara merupakan sebuah set pertanyaan yang diberikan kepada responden terpilih tentang hal yang berkaitan dengan maksud penelitian (Nazir, 2003)

\section{Metode Analisis Data}

Metode analisis data dalam penelitian ini menggunakan analisis statistik deskriptif, uji CFA, uji reliabilitas, serta dengan menggunakan SEM analisis yang akan menggunakan WarpPLS.7

Uji CFA dilalukukan untuk menguji ketepatan item-item pertanyaan kusioner dalam mengukur variable penelitian. Uji reliabilitas dilakukan untuk menguji kehadalan kusioner, dalam pengukuran variable penelitian menghasislak pengukurang yang konsisten. Selanjutnya yaitu SEM analisis adalah pengujian validitas model, sahih tidaknya suatu analisis bergantung pada terpenuhinya atau tidak asumsi yang melandasinya.

\section{RESULT AND DISCUSSION}

Responden penelitian ini adalah karyawan hotel di jember yang jumlahnya 120 orang. Karakteristik responden dibedakan berdasarkan usia dan jenis karyawan, karakteristik responden responden berusia antara $<25$ tahun sebasar $8 \%$ atau sebanyak 9 orang, usia antara 26 35 tahun sebesar $43 \%$ atau sebanyak 51 orang, usia antara 36 - 45 tahun sebesar $20 \%$ atau sebanyak 24 orang kemudian usia antara 46 - 55 tahun sebesar 28\% atau sebanyak 33 orang dan usia antara $>56$ tahun sebesar $3 \%$ atau sebanyak 3 orang. jumlah responden yang menjadi karyawan tetap sebanyak 72 orang atau $60 \%$, jumlah responden yang menjadi karyawan tidak tetap yaitu sebanyak 48 orang atau $40 \%$.
(a) Combined Loading and Cross Loading.

Tabel 1

Combined Loading and Cross Loading

\begin{tabular}{|l|r|r|r|r|r|l|}
\hline & \multicolumn{1}{l|}{ konflik } & stress & motivas & perform & SE & P value \\
\hline $\mathrm{x} 1.2$ & 0.735 & -0.232 & -0.277 & 0.28 & 0.067 & $<0.001$ \\
\hline $\mathrm{x} 1.3$ & 0.765 & 0.286 & -0.143 & 0.124 & 0.072 & $<0.001$ \\
\hline $\mathrm{x} 1.4$ & 0.502 & -0.077 & 0.457 & -0.392 & 0.125 & $<0.001$ \\
\hline $\mathrm{x} 1.5$ & 0.719 & -0.007 & 0.433 & -0.429 & 0.097 & $<0.001$ \\
\hline $\mathrm{x} 1.6$ & 0.742 & -0.009 & 0.415 & -0.379 & 0.097 & $<0.001$ \\
\hline $\mathrm{x} 1.7$ & 0.731 & -0.275 & -0.197 & 0.146 & 0.072 & $<0.001$ \\
\hline $\mathrm{x} 1.8$ & 0.785 & 0.132 & -0.253 & 0.303 & 0.067 & $<0.001$ \\
\hline $\mathrm{x} 1.9$ & 0.675 & -0.041 & -0.155 & 0.087 & 0.095 & $<0.001$ \\
\hline $\mathrm{z1.2}$ & -0.126 & 0.607 & 0.02 & 0.051 & 0.117 & $<0.001$ \\
\hline $\mathrm{z} 1.5$ & 0.024 & 0.599 & 0.119 & -0.126 & 0.109 & $<0.001$ \\
\hline $\mathrm{z} 1.6$ & 0.171 & 0.658 & 0.026 & 0.23 & 0.104 & $<0.001$ \\
\hline $\mathrm{z1.7}$ & 0.12 & 0.826 & -0.119 & 0.02 & 0.051 & $<0.001$ \\
\hline $\mathrm{z} 1.8$ & -0.112 & 0.542 & 0.372 & -0.44 & 0.142 & $<0.001$ \\
\hline $\mathrm{z1.9}$ & -0.152 & 0.756 & -0.219 & 0.145 & 0.082 & $<0.001$ \\
\hline $\mathrm{z2.1}$ & 0.116 & 0.107 & 0.663 & -0.149 & 0.076 & $<0.001$ \\
\hline $\mathrm{z2.2}$ & 0.1 & -0.157 & 0.861 & -0.02 & 0.104 & $<0.001$ \\
\hline $\mathrm{z2.3}$ & 0.126 & 0.013 & 0.821 & -0.162 & 0.101 & $<0.001$ \\
\hline $\mathrm{z2.5}$ & -0.307 & 0.113 & 0.601 & 0.263 & 0.167 & $<0.001$ \\
\hline $\mathrm{y} 1$ & 0.219 & -0.427 & -0.098 & 0.705 & 0.181 & $<0.001$ \\
\hline $\mathrm{y} 2$ & 0.036 & 0.074 & 0.051 & 0.779 & 0.124 & $<0.001$ \\
\hline $\mathrm{y} 6$ & -0.223 & 0.371 & 0.139 & 0.586 & 0.174 & $<0.001$ \\
\hline $\mathrm{y} 8$ & -0.11 & 0.078 & 0.048 & 0.883 & 0.171 & $<0.001$ \\
\hline $\mathrm{y} 9$ & 0.127 & -0.11 & -0.201 & 0.634 & 0.133 & $<0.001$ \\
\hline
\end{tabular}

Variabel dengan nilai loading rendah menunjukan bahwa indikator tidak berpengaruh dengan baik pada indikator reflektif $>0,7$, sedangkan variabel formatif setiap variabel memberikan kontribusi terbesar dalam kontruk. Pada alpha 5\% dan t-statistik >1. 97993. Cross loading merupakan ukuran lain dari validitas diskrimanan

Hasil pengujian combined loading and cross loading ialah menguji indikator refektif dan formatif pada penelitian ini dengan p-value sebesar $<0,001$ semua variable penelitian, dinyatakan signifikan karena $<0,05$.

(b) Average Variance External

\section{Tabel 2}

Average Variance Extracted

\begin{tabular}{llll}
\hline konflik & stress & Motivasi & Kinerja \\
\hline 0.507 & 0.452 & 0.554 & 0.526
\end{tabular}

Sumber : Data diolah (output WarpPls 7.0)

Berdasarkan tabel diatas yang menyatakan bahwa AVE dapat digunakan untuk mengukur banyaknya varians dalam 
Sadar Wisata: Jurnal Pariwisata

(p- ISSN 1858-0112, e-ISSN 15537-37677)

kostruk dibandingkan oleh variansi yang ditimbulkan dalam pengukuran. Hasil pengujian AVE dalam penelitian ini sebesar konflik kerja bernilai 0.507 ; stress kerja bernilai 0.452; motivasi kerja bernilai 0,554; dan kinerja karyawan bernilai 0.526 , nilai AVE sudah melebihi 0.05. Sehingga sudah memenuhi standar dari nilai AVE.

(c) Model fit

Uji ini tujuannya menguji tingkat kesesuian model penelitian secara keseluruhan. Pengujian signifikansi variabel independen terhadap variabel dependen pengujian dapat dinyatakan signifikan dengan memenuhi syarat jika $\mathrm{P}$ value kurang dari 0.05. Berikut ini adalah hasil output model fit indices yang disajikandalam tabel yaitu:

\section{Tabel 3}

Model Fit Indices

\begin{tabular}{|c|c|c|c|}
\hline Model & $\begin{array}{c}\text { Fit } \\
\text { Indic } \\
\text { es }\end{array}$ & Values iteria & erangan \\
\hline APC & 0.298 & $<0.001,<0,05$ & Diterima \\
\hline ARS & 0,276 & $<0.001 \quad>0,05$ & Diterima \\
\hline $\begin{array}{c}\text { R- } \\
\text { Squared }\end{array}$ & 0.263 & $<0.001 \quad>0,05$ & Diterima \\
\hline AVIF & 1.547 & $\mathrm{dd}$ if $<5$ IF $<5$ & Diterima \\
\hline GoF & 0.375 & $\begin{array}{c}\text { small } \geq 0,1 \\
\text { medium } \\
\geq 0,25, \text { large } \\
\geq 0,36\end{array}$ & Large \\
\hline SPR & 0.833 & $\begin{array}{c}\geq 0,7 \text { dan } \\
\text { idealnya }=1\end{array}$ & iterima \\
\hline RSCR & 0.983 & $\begin{array}{c}\geq 0,9 \text { dan } \\
\text { idealnya }=1\end{array}$ & iterima \\
\hline SSR & 1.000 & $\geq 0,9$ & iterima \\
\hline NLBCDR & 1.000 & $\geq 0,7$ & iterima \\
\hline
\end{tabular}

Sumber : Data diolah (output WarpPls 7.0)

Hasil output pada table di atas, menjelaskan bahwa APC memiliki indeks sebesar 0, 298 dengan nilai $\mathrm{p}$-value $<0,001$. Sedangkan ARS memiliki indeks sebesar 0, 276 dengan p-value $<0,001$. Berdasarkan kriteria, APC sudah memenuhi kriteria
Volume 3 No. 1 Juni Tahun 2020

http://jurnal.unmuhjember.ac.id/index.php/wisata

karena memiliki nilai $\mathrm{p}<0,001$. Begitu pula dengan nilai p-value dari ARS yaitu $\mathrm{p}<0.001<0,05$. Nilai AVIF yang harus $<5$ sudah terpenuhi karena berdasarkan data tersebut AVIF nilainya 1,547. data penelitian diuji dengan model fit dan data penelitian dinyatakan fit sehingga data penelitian ini tidak terjadi multikolirearitas. Dengan demikian, maka inner model dapat diterima

(d) Path coefficient and P-values

Pada bagian ini menguraikan tiap-tiap jalur pada bagian model dengan menggunakan analisis jalur (Path coefficient). Tiap-tiap jalur yang diuji menunjukkan pengaruh langsung dan tidak langsung konflik kerja (X1), stress kerja (Z1), motivasi kerja (Z2), kenerja karyawan (Y) di hotel Jember. Nilai koefisien jalur dapat dilihat pada tabel berikut:

\section{Tabel 4}

Nilai Koefisien Jalur Pengaruh Langsung

\begin{tabular}{|c|c|c|c|c|}
\hline & & & $\begin{array}{r}\text { Estimat } \\
\mathrm{e}\end{array}$ & P Label \\
\hline stress & $<$ & $\begin{array}{r}\text { konfli } \\
\mathrm{k}\end{array}$ & 0,559 & ' signifika \\
\hline motiv & $<$ & $\begin{array}{r}\text { konfli } \\
\mathrm{k}\end{array}$ & $-0,301$ & $\underset{\mathrm{n}}{\text { I signifika }}$ \\
\hline $\begin{array}{r}\text { kinerj } \\
\mathrm{a}\end{array}$ & $<$ & $\begin{array}{r}\text { konfli } \\
\mathrm{k}\end{array}$ & $-0,110$ & ,15 tidak \\
\hline motiv & $<$ & stress & $-0,239$ & ,05 tidak \\
\hline $\begin{array}{r}\text { kinerj } \\
\mathrm{a}\end{array}$ & $<$ & stress & 0,080 & ,31 tidak \\
\hline $\begin{array}{r}\text { kinerj } \\
\mathrm{a}\end{array}$ & $<$ & motiv & 0,461 & $\underset{\mathrm{n}}{, 00} \underset{\text { signifika }}{\cos }$ \\
\hline
\end{tabular}

Sumber: Hasil Pengolahan data 2020

a. Pengaruh Variabel konflik $\operatorname{kerja}(X)$ terhadap stress Kerja (Z1)

Berdasarkan Tabel 4 dapat dilihat untuk pengujian variabel konflik kerja (X) 
Sadar Wisata: Jurnal Pariwisata

(p- ISSN 1858-0112, e-ISSN 15537-37677)

terhadap stress kerja diperoleh nilai beta $(\beta)$ sebesar 0,559 dengan $\rho$-value sebesar 0,001. Karena nilai $\rho$-value lebih kecil dari pada $\alpha$ $(0,000<0,05)$ maka H0 ditolak dengan demikian ada pengaruh positif secara signifikan konflik kerja (X) terhadap stress kerja (Z1).

b. Pengaruh Variabel konflik kerja (X) terhadap motivasi kerja (Z2)

Berdasarkan Tabel 4 dapat dilihat untuk pengujian variabel konflik kerja (X) terhadap motivasi kerja (Z2) diperoleh nilai beta $(\beta)$ sebesar $-0,301$ dengan $\rho$-value sebesar 0,014. Karena nilai $\rho$-value lebih kecil dari pada $\alpha(0,014<0,05)$ maka $\mathrm{H} 0$ ditolak dengan demikian ada pengaruh nigatip secara signifikan konflik kerja (X) terhadap motivasi kerja (Z2).

c. Pengaruh Variabel konflik kerja (X) terhadap kinerja karyawan (Y)

Berdasarkan Tabel 4 dapat dilihat untuk pengujian variabel konflik kerja (X) terhadap kinerja karyawan (Y) diperoleh nilai beta $(\beta)$ sebesar $-0,110$ dengan $\rho$-value sebesar 0,153 . Karena nilai $\rho$-value lebih besa dari pada $\alpha(0,153<0,05)$ maka $\mathrm{H} 0$ diterima dengan demikian ada pengaruh nigatip tetapi tidak signifikan konflik kerja (X) terhadap kinerja karyawan (Y).

d. Pengaruh Variabel stress kerja (Z1) terhadap motivasi kerja (Z2)

Berdasarkan Tabel 4 dapat dilihat untuk pengujian variabel stress kerja (Z1) terhadap motivasi kerja $(Z 2)$ diperoleh nilai beta $(\beta)$ sebesar -0,239 dengan $\rho$-value sebesar 0,057 . Karena nilai $\rho$-value lebih besa dari pada $\alpha(0,057<0,05)$ maka H0 diterima dengan demikian ada pengaruh nigatip tetapi tidak signifikan stress kerja (Z1) terhadap motivasi kerja (Z2).

e. Pengaruh Variabel stress kerja (Z1) terhadap kinerja karyawan (Y)

Berdasarkan Tabel 4 dapat dilihat untuk pengujian variabel stress kerja (Z1) terhadap kinerja karyawan (Y) diperoleh nilai beta $(\beta)$ sebesar 0,080 dengan $\rho$-value sebesar
Volume 3 No. 1 Juni Tahun 2020

http://jurnal.unmuhjember.ac.id/index.php/wisata

0,310 . Karena nilai $\rho$-value lebih besa dari pada $\alpha(0,310<0,05)$ maka $\mathrm{H} 0$ diterima dengan demikian ada pengaruh positif tetapi tidak signifikan stress kerja (Z1) terhadap kinerja karyawan (Y).

f. Pengaruh Variabel motivasi kerja (Z2) terhadap kinerja karyawan (Y)

Berdasarkan Tabel 4 dapat dilihat untuk pengujian variabel motivasi kerja (Z2) terhadap kinerja karyawan (Y) diperoleh nilai beta $(\beta)$ sebesar 0,461 dengan $\rho$-value sebesar 0,001. Karena nilai $\rho$-value lebih kecil dari pada $\alpha(0,001<0,05)$ maka $\mathrm{H} 0$ ditolak dengan demikian ada pengaruh positif secara signifikan stress kerja (Z) terhadap kinerja karyawan (Y).

\section{(e) Model Struktural}

Bagian ini menjelaskan perhitungan pengaruh variabel pengeruh konflik kerja (X) terhadap kinerjakaryawan (Y) denganstress kerja (Z1) dan motivasikerja (Z2) sebagai variabel intrviening, dan Path Coefficienthasil pengujian koefisien jalur disajikan sebagai berikut:

\section{Gambar 1}

Path Coefficient dan P-Values

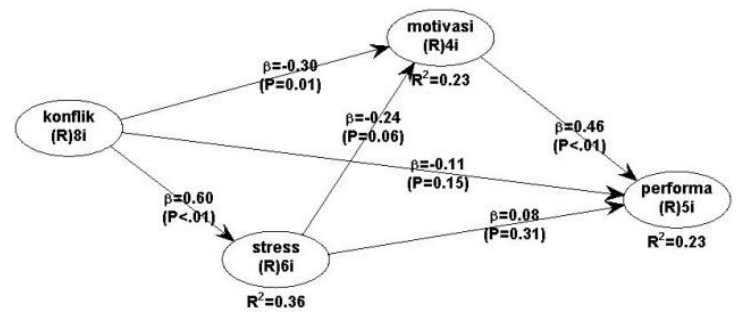

Sumber: Hasil Pengolahan data 2020

Dengan mendasarkan pengujian koefisien jalur seperti pada tabel 4, maka model dalam bentuk diagram path hasil pengujian koefisien jalur disajikan pada gambar 1, model tersebut juga dapat dinyatakan dalam bentuk persamaan (system persamaan simultan). Analisis jalur dalam bentuk persamaan disajikan sebagai berikut:

Z1stress kerja $\quad=0,060$ konflik

Z2stress kerja $=0,030$ konflik +

0,240 stress 
Sadar Wisata: Jurnal Pariwisata

(p- ISSN 1858-0112, e-ISSN 15537-37677)

Y kinerja $\quad=\begin{gathered}0,11 \text { konflik }+ \\ 0,080 \text { stress }+0,46\end{gathered}$ motivasi

(f) Perhitungan Koefisien Jalur

Pengaruh Tidak Langsung

Pengujian pengaruh tidak langsung dilakukan dengan melihat hasil pengujian jalur yang dilalui, jika semua jalur yang dilalui signifikan maka pengaruh tidak langsungnya juga signifikan, dan jika terdapat jalur yang non signifikan maka pengaruh tidak langsungnya dikatakan non signifikan. Koefisien jalur pengaruh tidak langsung disajikan pada tabel 4.20

\section{Tabel 5}

Pengujian Perngaruh Variabel Intervening

\begin{tabular}{|l|l|l|}
\hline & $\begin{array}{l}\text { konflik }- \\
\text { Kinerja } \\
\text { karyawan }\end{array}$ & $\begin{array}{l}\text { stress - } \\
\text { Kinerja } \\
\text { karyawan }\end{array}$ \\
\hline $\begin{array}{l}\text { Pengaruh } \\
\text { Langsung }\end{array}$ & $=0,110$ & $=0,080$ \\
\hline $\begin{array}{l}\text { Pengaruh } \\
\text { Tidak } \\
\text { Langsung }\end{array}$ & $\begin{array}{l}=0,599+(- \\
0,444)+(- \\
0,267)\end{array}$ & $\begin{array}{l}=-0,239+- \\
0,030 \\
=-0,269\end{array}$ \\
\hline $\begin{array}{l}\text { P values for } \\
\text { total effects }\end{array}$ & 0,001 & 0,424 \\
\hline $\begin{array}{l}\text { Pengaruh } \\
\text { Total }\end{array}$ & $\begin{array}{l}0,110+(- \\
0,152)\end{array}$ & $\begin{array}{l}=0,080+(- \\
0,269) \\
-0.180\end{array}$ \\
\hline Kesimpulan & $\begin{array}{l}\text { Pengaruh langsung }> \\
\text { Pengaruh tidak langsung : }\end{array}$ \\
& $\begin{array}{l}\text { Variabel konflik } \\
\text { kerjabersinergi dengan }\end{array}$ \\
& $\begin{array}{l}\text { variabel stress kerja, } \\
\text { motivasi kerja untuk }\end{array}$ \\
\hline
\end{tabular}

Sumber: Hasil Pengolahan data 2020

Dari informasi yang disajikan dalam Tabel 5, diketahui bahwa pengaruh konflik kerjaterhadap kinerja karyawan masingmasing memiliki pengaruh langsung yang sama besar dari pengaruh tidak langsungnya, artinya stress dan motivasi kerja bersinergi dengan variabel konflik kerjadalam
Volume 3 No. 1 Juni Tahun 2020

http://jurnal.unmuhjember.ac.id/index.php/wisata

meningkatkan kinerja karyawan di hotel di jember. Lebih jelasnya sebagai berikut:

a. Konflik kerja berpengaruh positif terhadap kinerjapegawai melalui stress kerja dan motivasi kerja (sebagai intervening)

Berdasarkan Tabel 5 dapat dilihat untuk pengujian konflik kerja (X) terhadap kinerja karyawan (Y) melalui varibel intervening (stress kerja dan motivasi keerja) (Z) diperoleh nilai beta $(\beta)$ sebesar $-0,152$ dengan $\rho$-value sebesar 0,001 . Karena nilai $\rho$-value lebih kecil dari pada $\alpha(0,001<0,05)$ maka H0 ditolak dengan demikian ada pengaruh nigatif secara signifikan konflik kerja (X1) terhadap kinerja karyawan (Y). melalui varibel intervening (stress kerja dan motivasi keerja) (Z)

b. stress kerja berpengaruh positif terhadap kinerja pegawai melalui motivasi kerja (sebagai intervening)

Berdasarkan Tabel 5 dapat dilihat untuk pengujian variabel stress kerja (Z1) terhadap kinerjakaryawan(Y) melalui varibel intervening (motivasi keerja) (Z2) diperoleh nilai beta $(\beta)$ sebesar -0,269dengan $\rho$-value sebesar 0,424 . Karena nilai $\rho$-value lebih besar dari pada $\alpha(0,424<0,05)$ maka $\mathrm{H} 0$ diterima dengan demikian ada pengaruh nigatiftetapi tidak signifikan stress kerja (Z1) terhadap kinerjapegawai (Y) melalui varibel intervening (motivasi keerja) (Z2)

Hal tersebut dikarenakan konflik kerjayang ada di hotel jember memiliki dampak nigatif kepada kinerjakaryawan, dengan adanya konflik kerja yang menjadi stress kerja dan motivasi kerja secara extrinsik memberikan pengaruh pada kinerja karyawan dalam menjalankan pekerjaanya.i

\section{(g) Koefisien Determinasi}

Koefisien determinasi merupakan besaran yang menunjukkan besarnya variasi variabel dependen yang dapat dijelaskan oleh variabel independennya. Dengan kata lain, koefisien determinasi ini digunakan untuk mengukur seberapa jauh variabel- 
variabel bebas dalam menerangkan variabel terikatnya. Nilai koefisien determinasi pada penelitian ini adalah sebagai berikut:

\section{Tabel 6}

Koefisien Determinasi, Konflik

KerjaTerhadap Stress Kerja Model Summary ${ }^{b}$

\begin{tabular}{|c|r|r|}
\hline Model & R Square & $\begin{array}{r}\text { Adjusted R } \\
\text { Square }\end{array}$ \\
\hline 1 &, 359 &, 353 \\
\hline
\end{tabular}

a. Predictors: (Constant), konflik kerj

b. Dependent Variable: stress kerja

Sumber: Lampiran

Pengaruh e1 (variabel selain, konflik kerja terhadap stress kerja)

$$
\begin{aligned}
& =\sqrt{ } 1-\mathrm{R}^{2} \\
& =\sqrt{ } 1-0,353^{2} \\
& =\sqrt{ } 1-0,125 \\
& =0,875 \text { atau } 87,5 \%
\end{aligned}
$$

\section{Tabel 7}

\section{Koefisien Determinasi, Konflik KerjaDan} Stress KerjaTerhadap Motivasi

Kerja

Model Summary ${ }^{b}$

\begin{tabular}{|c|r|r|}
\hline Model & R Square & $\begin{array}{r}\text { Adjusted R } \\
\text { Square }\end{array}$ \\
\hline 1 &, 234 &, 221 \\
\hline
\end{tabular}

a. Predictors: (Constant), konfli kerja dan stress kerja

b. Dependent Variable: motivasi kerj

Sumber: Lampiran

Pengaruh e1 (variabel selain, konflik kerja dan stress kerja terhadap motivasi kerja)

$$
\begin{aligned}
& =\sqrt{ } 1-\mathrm{R}^{2} \\
& =\sqrt{ } 1-0,221^{2} \\
& =\sqrt{ } 1-0,049 \\
& =0,951 \text { atau } 95,1 \%
\end{aligned}
$$

\section{Tabel 8}

Koefisien Determinasi, Konflik Kerja,Stress Kerjadan Motivasi Kerja Terhadap Kinerja Karyawan Model Summary ${ }^{b}$

\begin{tabular}{|c|r|r|}
\hline Model & R Square & $\begin{array}{r}\text { Adjusted R } \\
\text { Square }\end{array}$ \\
\hline 1 &, 234 &, 214 \\
\hline
\end{tabular}

a. Predictors: (Constant), konfli kerja, stress kerja dan motivasi kerja
b. Dependent Variable: kinerja karyawan

Sumber: Lampiran

Pengaruh $\epsilon 1$ (variabel selain, konflik kerja, stress kerja dan motivasi kerja terhadap kinerja karyawan)

$$
\begin{aligned}
& =\sqrt{1-\mathrm{R}^{2}} \\
& =\sqrt{1}-0,214^{2} \\
& =\sqrt{1}-0,046 \\
& =0,954 \text { atau } 95,4 \%
\end{aligned}
$$

Koefisien determinasi Total :

$$
\begin{aligned}
& \quad R_{m}^{2}=1-P_{e 1}^{2} P_{e 2}^{2} P_{e 3}^{3} \\
& R_{m}^{2} \\
& =1-(0,875)^{2} \cdot(0,951)^{2} \cdot(0,954)^{2} \\
& \quad=1-(0,766 \cdot 0,904 \cdot 0,910) \\
& =1-0,063 \\
& =0,937
\end{aligned}
$$

Hasil perhitungan SEM dapat diketahui bahwa koefisien determinasi R2 total diperoleh nilai sebesar 0,937. Hal ini berarti 93,7\% variasi variabel konfli $\operatorname{kerja}(X)$, stress kerja (Z1), motivasi kerja (Z2), kinerjakaryawan (Y), sedangkan sisanya sebesar 6,3\% diterangkan oleh variabel lain dan error yang tidak dijelaskan dalam penelitian ini.

\section{KESIMPULAN}

Konflik kerja secara langung mempengaruhi kinerja karyawan secara nigatif, dengan adanya konflik kerja justru 
Sadar Wisata: Jurnal Pariwisata

(p- ISSN 1858-0112, e-ISSN 15537-37677)

karyawan mengalami stress kerja ini terbukti dalam penelitian ini, juga berdampak pada motivasi kerja yang mempengaruhi secara nigatif juga, sedangkan motivasi secara langsung mempengaruhi kinerja secara signifikan

\section{DAFTAR PUSTAKA}

Faozen. 2019. Work Stress: Antesedent Variables And Its Impact On Employee Motivation And Performance (Case Study At The University Of Muhammadiyah Jember). ICOGISS 2019. 1, pp. 536-553. Jember: jurnal.unmuhjember.ac.id.

doi:http://dx.doi.org/10.32528/pi.v0i0.2 521.

Ramdhani 2011, Pelaksanaan Program Pelatihan dan Kompetensi Pengaruhnya Terhadap Kinerja Karyawan di PT Otto Phrmaceutical Industries, Tesis Magister Manajemen ,Universitas Bina Nusantara

Yuli Tania,2010, Analisis Pengaruh Stress Kerja, Konflik Kerja Dan Motivasi Kerja Terhadap Kinerja Karyawan Pada Pt. Cempaka Bersamamaju, Tesis Magister Manajemen ,Universitas Bina Nusantara

Yulianti Praptini, 2000. Pengaruh SumberSumber Stres Kerja Terhadap Kepuasan Kerja Tenaga Edukatif tetap Fakultas Ilmu Sosial Universitas Airlangga Di Surabaya. Tesis tidak diterbitkan. Surabaya : Program Pascasarjana Ilmu Manajemen Universitas Airlangga

Dimyati. 2009. Belajar dan Pembelajaran. Jakarta: Rineka Cipta

Owens, Robert G. 1995. Organizatoinal Behavior in Education. Allyn and Bacon.Boston

Robbins, Stephen P, 2003. Perilaku Organisasi. Jakarta, Gramedia,

Mangkunegara, A.A Anwar Prabu, 2002, Manajemen Sumber Daya Manusia, PT.Remaja Rosda Karya, Bandung
Volume 3 No. 1 Juni Tahun 2020

http://jurnal.unmuhjember.ac.id/index.php/wisata

Mangkunegara, A A Anwar Prabu 2001, Manajemen sumber daya manusiaperusahaan, Bandung : Remaja Rosdakarya.

Nawawi, Hadari. 2001. Metodologi Penelitian Bidang Sosial. Yogyakarta :Gajah Mada University Press.

Sedarmayanti. 2001. Sumber Daya Manusia dan Produktivitas Kerja. Bandung:Mandar Maju

Prawirosentono, Suyadi.1999. Manajemen sumber Daya Manusia ( KebijakanKinerja Karyawan), Kiat membangun Organisasi Kompetitif menjelangPerdagangan Bebas Dunia, Edisi Pertama. Yogyakarta;BPFE

Nazir,M. 2003. Metode Penelitian. Jakarta : Ghalia Indonesia 